\title{
Cancer Genetics and Therapeutic Opportunities in Urologic Practice
}

\author{
Jacob J. Adashek ${ }^{1}{ }^{(}$, Alex Leonard ${ }^{2}$, Jason Roszik ${ }^{3}{ }^{\circledR}$, Arjun K. Menta ${ }^{4}$, Giannicola Genovese ${ }^{5}$, \\ Vivek Subbiah ${ }^{6, *}$ and Pavlos Msaouel ${ }^{5, *}$ \\ 1 Department of Internal Medicine, University of South Florida, H. Lee Moffitt Cancer Center \& Research \\ Institute, Tampa, FL 33606, USA; jadashek@westernu.edu \\ 2 Morsani College of Medicine, University of South Florida, Tampa, FL 33612, USA; \\ alexleonard@health.usf.edu \\ 3 Departments of Genomic Medicine and Melanoma Medical Oncology, The University of Texas MD \\ Anderson Cancer Center, Houston, TX 77030, USA; jroszik@mdanderson.org \\ 4 The University of Texas at Austin, Austin, TX 78712, USA; arjunkmenta@gmail.com \\ 5 Department of Genitourinary Medical Oncology, Division of Cancer Medicine, The University of Texas MD \\ Anderson Cancer Center, Houston, TX 77030, USA; ggenovese@mdanderson.org \\ 6 Department of Investigational Cancer Therapeutics, Division of Cancer Medicine, The University of Texas \\ MD Anderson Cancer Center, Houston, TX 77030, USA \\ * Correspondence: vsubbiah@mdanderson.org (V.S.); pmsaouel@mdanderson.org (P.M.); \\ Tel.: +1-713-563-1930 (V.S.); +1-713-563-4585 (P.M.); Fax: +1-713-792-0334 (V.S.); +1-713-745-0422 (P.M.)
}

Received: 31 January 2020; Accepted: 15 March 2020; Published: 18 March 2020

\begin{abstract}
This article aims to summarize the current literature on genetic alterations related to tumors of the genitourinary tract. Novel associations have recently been reported between specific DNA alterations and genitourinary malignancies. The most common cause of chromosome $3 p$ loss in clear cell renal cell carcinoma is a chromothripsis event, which concurrently generates a chromosome $5 q$ gain. Specific patterns of clear cell renal cell carcinoma metastatic evolution have been uncovered. The first therapy targeting a specific molecular alteration has now been approved for urothelial carcinoma. Germline mutations in DNA damage repair genes and the transcription factor HOXB13 are associated with prostate cancer and may be targeted therapeutically. The genetic associations noted across different genitourinary cancers can inform potential screening approaches and guide novel targeted treatment strategies.
\end{abstract}

Keywords: cancer genetics; urologic oncology; urology; next-generation sequencing

\section{Introduction}

Much of what is known about genitourinary (GU) cancers derives from the well-characterized genetic alterations in various hereditary syndromes (Figure 1). Using hereditary syndromes as assumptive models for sporadic, somatic disease processes allows investigators to make valuable biological and therapeutic inferences. Herein, we summarize recent developments in cancer genetics related to GU malignancies.

In renal cell carcinoma (RCC), von Hippel Lindau (VHL) disease, Birt-Hogg-Dubé (BHD) syndrome, and hereditary papillary renal carcinoma (HPRCC) have provided substantial insight into the pathogenesis of spontaneous RCC. Clear cell RCC (ccRCC), the most common form of RCC, is associated with alterations in the $V H L$ gene causing a cascade of events, ultimately increasing the expression of vascular growth factors (VEGF). BHD is associated with activation of the mTOR genes in various types RCC, and HPRCC is known for its association to the MET gene [1-3]. All these pathways are well-described in RCC and can be therapeutically targeted [4]. 
Bladder cancers can be divided into low-grade and high-grade urothelial carcinomas, with each having distinct genetic aberrations. Mutations in FGFR3 or HRAS are found in $65 \%-80 \%$ of low-grade cases and are less frequent in high-grade tumors, which are more likely to harbor mutations in TP53 or $R b$ [5]. Understanding these key genomic alterations is paramount in recognizing the diversity of biology in bladder cancer. Other implicated pathways include PIK3CA-mTOR as well as BAP1 [6]. The landscape of genomic alterations in bladder cancer and the intricate roles these mutations play in tumor proliferation can guide clinically effective treatment modalities. Recently, the first targeted therapy for urothelial carcinomas, erdafitinib, was approved by the FDA for the treatment of tumors harboring FGFR2 and FGFR3 alterations [7].
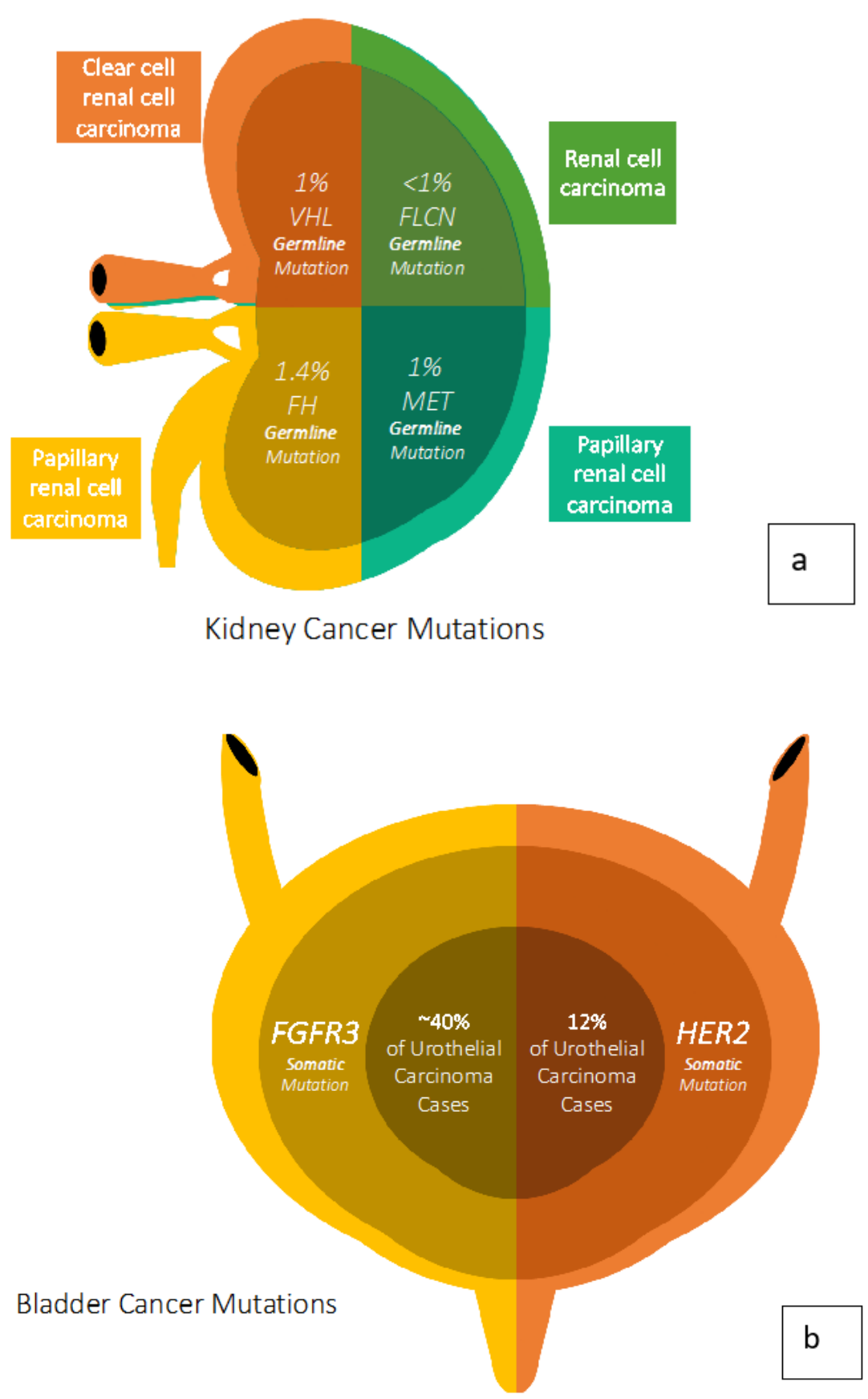

Figure 1. Cont. 


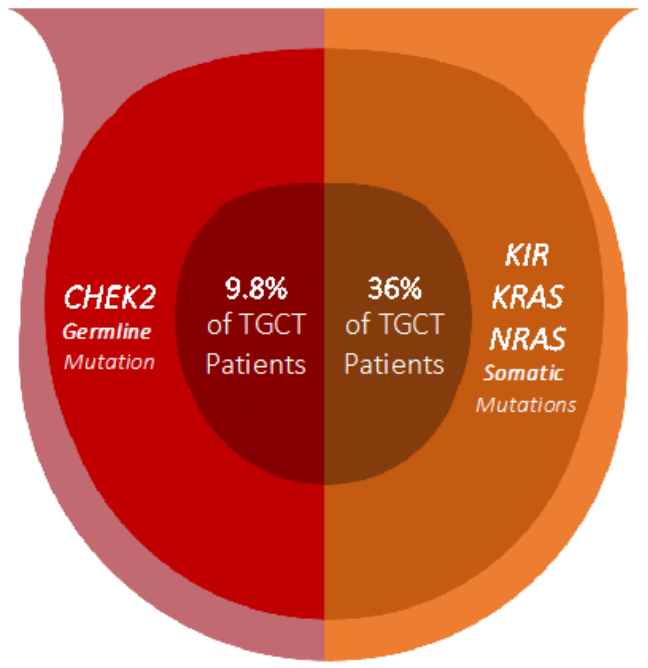

\section{Testicular Cancer Mutations}

\section{Prostate Cancer Mutations}

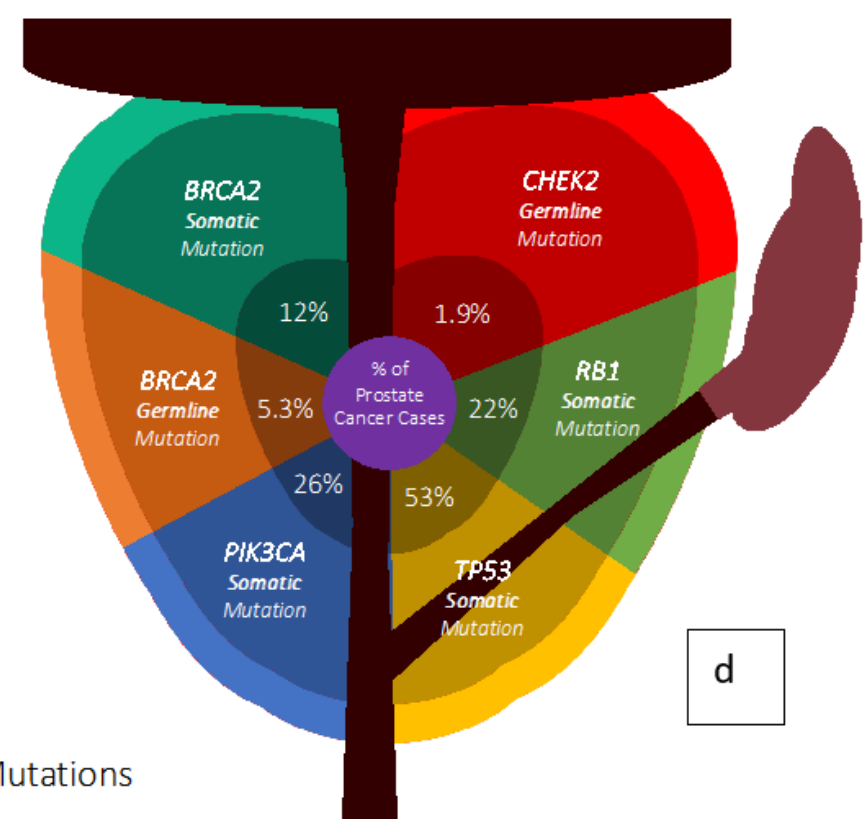

Figure 1. Germline and Somatic mutations found across tumor types. (a) Kidney Cancer Mutations, (b) Bladder Cancer Mutations, (c) Testicular Cancer Mutations, (d) Prostate Cancer Mutations.

Germline mutations in the transcription factor HOXB13 and DNA damage repair genes such as $B R C A 1, B R C A 2, C H E K 2$, as well as the mismatch repair (MMR) genes MSH6 and PMS2, have been shown to increase the risk of prostate cancer, the most common cancer among men [8-13]. For patients with $B R C A 1, B R C A 2$, and ATM alterations, there is now an FDA breakthrough designation for the use of olaparib, a poly ADP-ribose polymerase (PARP) inhibitor, in metastatic castration-resistant prostate cancer (mCRPC) [14]. Similarly, immunotherapy (IO) with pembrolizumab is now recommended by the National Comprehensive Cancer Network guidelines for MMR-deficient mCRPC [15].

In testicular germ cell tumors (TGCT), major genes associated with pathogenesis are TP53 and its regulator $M D M 2$ in both seminomas and nonseminomas [16]. Although these are not specific to testicular cancer, their high oncogenicity has allowed further exploration into genomic biomarkers. In TGCT, there is growing evidence that DNAAF1 mutations can also play a significant role in 
tumorigenesis [17]. Delineating molecular subtypes of testicular cancers can elucidate more genomic alterations and inform patient decision making.

\section{Kidney Cancer Genetics}

A phase II study of pazopanib in 31 patients with molecularly confirmed or clinically consistent VHL disease demonstrated an objective response rate (ORR) of $42 \%$ in VHL-associated tumors (RCC, pancreatic lesions, and hemangioblastomas) pointing towards the clinical utility of pazopanib in this setting [18]. This is the first systemic therapy to show such encouraging efficacy in patients with VHL disease.

In the context of hereditary papillary RCC (HPRCC), the defining MET mutation has informed the design of various trials in sporadic papillary RCC with MET inhibitors. Treatment with MET inhibitors may lead to better outcomes in patients with MET-driven vs MET-independent papillary RCC [19]. Molecular insights into the role of MET in HPRCC informed the design of ongoing clinical trials such as SWOG1500 trial, which originally compared the VEGF inhibitor sunitinib to three different MET inhibitors (cabozantinib, crizotinib, and savolitinib) for the treatment of papillary RCC [20].

In Birt-Hogg-Dubé (BHD) syndrome, individuals are often afflicted with skin tumors, lung disease, and chromophobe RCC due to mutations in FLCN [21] leading to the downstream activation of mTOR, via the loss of negative inhibition by the BHD protein, similarly to how TSC1 and TSC2 complexes downregulate mTOR activity [21]. Patients with FLCN mutations and subsequent BHD, can provide valuable clinical insights on how chromophobe RCC will respond to the inhibition of the Akt-mTOR pathway [22]. In addition to modeling Akt-mTOR altered RCC, there is also growing evidence that hypoxia-inducible factor (HIF) is upregulated in FLCN-deficient RCC [23]. Increased levels of HIF lends itself to be targeted via HIF inhibitors, which are currently being evaluated in clinical trials. The loss of FLCN may warrant the dual blockade of Akt-mTOR and HIF pathways, which are both independent pathologic events in RCC.

In almost all (>90\%) clear cell RCC (ccRCC) cases, the initial pathogenetic event is the loss of the $3 p$ chromosome arm, which harbors the VHL gene [24]. The TRACERx Renal study recently reported that the most common mechanism of 3p loss in both sporadic and VHL-associated ccRCC is a chromothripsis event, which generates a concurrent gain of the $5 q$ chromosome arm [25]. The same group found by analyzing 575 primary and 335 metastatic RCC samples that $87 \%$ of clonal variants in metastases are the same as in the primary tissue. Of the variants found in metastatic sites, only $5.4 \%$ were de novo mutations in driver genes such as VHL, BAP1, and $m T O R$ [26]. Metastatic sites demonstrated different characteristics based on whether they harbored mutations in either BAP1 or PBRM1. BAP1-driven tumors were characterized by increased tumor heterogeneity as well as high genomic instability and may thus be vulnerable to immunotherapeutic targets. On the other hand, PBRM1-mutated cases demonstrated more indolent clinical behavior and may benefit from cytoreductive nephrectomy [27]. Germline mutations in the BAP1 gene have also been associated with BAP1-tumor predisposition syndrome which carries an increased risk of developing uveal melanoma, cutaneous melanoma, malignant mesothelioma, RCC, meningioma, and cholangiocarcinoma. Some groups recommend that, in patients who develop RCC at $<46$ years old, germline testing for BAP1 mutations may identify earlier BAP1-tumor predisposition syndrome patients and offer better surveillance [28]. Another study found that among 181 families afflicted with BAP1-tumor predisposition syndrome, there were 140 unique germline variants in the BAP1 gene [29]. This study found that $97.5 \%$ of missense variant carriers developed a BAP1-associated tumor, of which $12 \%$ were RCC [29].

An interesting subset of kidney cancer is renal medullary carcinoma (RMC), which is a rare RCC subtype that predominantly affects young African Americans with sickle cell trait or other sickle hemoglobinopathies [30,31]. The SMARCB1 (otherwise known as INI1, BAF47, or SNF5) tumor suppressor gene plays a key role in the pathogenesis of RMC, and all cases of RMC are defined by the loss of SMARCB1, as evidenced by immunohistochemistry [30]. RMC is a very aggressive form of RCC with poor overall survival following diagnosis, and shares some similarities to pediatric malignant 
rhabdoid tumors, which are also caused by SMARCB1 inactivation [32]. A common mechanism of SMARCB1 loss is inactivating translocations [30], and a recently proposed mechanism of RMC pathogenesis postulates that regional ischemia induced by red blood cell sickling in the renal medulla of individuals with sickle cell trait or other sickle hemoglobinopathies can activate aberrant DNA damage repair mechanisms that can drive deletions and translocations in SMARCB1, which is located within a highly fragile region of chromosome 22 [33]. Of note, RMC is resistant to the standard VEGF-directed therapies used for ccRCC and other RCC subtypes. A study of mosaic mouse models with inactivated SMARCB1 demonstrated that SMARCB1-negative tumors such as RMC are vulnerable to proteasome and autophagy blockade [34]. The sensitivity of RMC to proteasome inhibitors was further validated in a study of RMC cell lines [35]. An ongoing trial (NCT03587662) is thus now evaluating the efficacy of ixazomib, a potent proteasome inhibitor, in combination with gemcitabine and doxorubicin in patients with RMC and other SMARCB1-negative kidney malignancies.

Fumarate hydratase (FH) mutations are associated with aggressive papillary type 2 renal cell carcinoma termed FH-deficient renal cell carcinoma (FH-RCC) [36,37]. The majority of FH-RCC cases are associated with germline FH mutations as part of the hereditary leiomyomatosis and renal cell carcinoma (HLRCC) syndrome characterized by cutaneous and uterine leiomyomas and increased risk of FH-RCC [36,38]. FH is a tricarboxylic acid (TCA) cycle enzyme and thus FH-RCC tumors are characterized by impairment of the TCA cycle and of oxidative phosphorylation with a resultant metabolic shift to aerobic glycolysis which can be therapeutically targeted by the combination of erlotinib (inhibitor of cell membrane glucose transporters) with bevacizumab (inhibitor of glucose delivery via tumor neovasculature) [36].

\section{Bladder Cancer Genetics}

In individuals diagnosed with bladder cancer, the odds ratio (OR) that another family member had a history of bladder cancer was 2.34 (95\% CI, 0.95-5.77) [39]. Whether this association is due to sharing a genetic driver or disease, or because certain shared family lifestyles may predispose an individual to develop bladder cancer is still unknown. Furthermore, in families afflicted by Lynch syndrome, the risk of developing urothelial carcinoma (UC), particularly of the upper tract, is significant [40]. The risk of developing UC before age 70 in men was $7.5 \%$ (95\% CI, 3.1-11.9\%) and in women $1.0 \%$ $(95 \%$ CI, $0-2.4 \%)$ [39]. These findings support the notion that there is a familial genetic component to developing UC.

Sex differences are notable in bladder cancer as men are at higher risk of developing bladder cancer, whereas women are diagnosed at a later stage and have higher stage-adjusted mortality [41]. Furthermore, female patients with non-invasive bladder cancer are approximately two-fold more likely than men ( $74 \%$ vs. $42 \%)$ to harbor KDM6A mutations [42]. This may be in part because KDM6A is located on the $\mathrm{X}$ chromosome. The male paralogue of KDM6A is the UTY gene located on Yq11 and is mutated in approximately $9 \%$ of male non-invasive bladder cancers [42].

Other pathogenic drivers have been identified in bladder cancer and multiple trials to target these aberrations are ongoing. Up to $40 \%$ of primary UC have FGFR3 mutations [43]. Patients with metastatic UC harboring FGFR3 mutations, have shown to have minimal to modest responses to IO. However, patients can have meaningful benefit when particular FGFR3 alterations are targeted with an inhibitor. Specifically, the FGFR inhibitors rogaratinib and erdafitinib have shown ORRs between $40.4-59 \%$ in patients who progressed on IO [44]. Erdafitinib recently became the first targeted therapy approved for metastatic UC harboring FGFR3 or FGFR2 mutations [7].

The FGFR3 surface receptor activates a cascade of events that lead to activation of Ras and the PIK3CA pathway. Mutations in FGFR3 and Ras can occur in UC but are likely mutually exclusive events in carcinogenesis, with Ras mutations noted in about $11 \%$ of UC cases [45,46]. Mutations in PIK3CA have been found in $24 \%$ of UC cases and can co-exist with FGFR3 mutations in $15 \%$ of UC cases, making combined targeted therapy an attractive approach [46,47]. 
Another appealing target in bladder cancer has been human epidermal growth factor receptor 2 (HER2), which is found in about $12 \%$ of UC cases [48]. HER2-directed therapies have shown significant survival advantages in multiple cancer types, including breast, gastric, and esophageal. Interestingly, a phase III HER2-directed trial using lapatinib in UC found no benefit in HER2-positive UC patients compared with placebo following progression on first-line chemotherapy [49]. Other trials have tested trastuzumab in combination with chemotherapeutics, but so far none has demonstrated a substantial positive impact on survival outcomes [50]. There continue to be ongoing trials investigating the role of HER2-directed treatments for patients with HER2 mutations, but as of yet the utility of this mutation as a biomarker of benefit to directed therapy remains unknown.

\section{Prostate Cancer Genetics}

The heritability of prostate cancer has been analyzed for close to 30 years, and some models attribute roughly $9 \%$ of prostate cancers by age 85 to be genetic in nature [51]. An analysis of over 100,000 Nordic twins found that the heritability of prostate cancer development was $58 \%$ (95\% CI, 52-63\%) [52]. This confirmed a previously published study on World War II veteran twins that reported genetic heritability of prostate cancer accounting for $57 \%$ of cases [53].

Mutations in DNA repair genes such as BRCA1, BRCA2, ATM, CHEK2, and PALB2 are of importance in prostate cancer. In a study of 82 patients, $11.8 \%$ had germline mutations in DNA repair genes namely BRCA2 (5.3\%), ATM (1.6\%), CHEK2 (1.9\%), BRCA1 (0.9\%), and PALB2 (0.4\%) [54]. There is growing evidence that a substantial number of patients may benefit from therapies targeting these alterations. Other studies have found that individuals with germline $B R C A 2$ mutations are three-fold to 8.6-fold more likely to develop high risk prostate cancer [55,56]. Looking into BRCA1, a study of 813 cases of prostate cancer found that having $B R C A 1$ germline mutations resulted in a 3.75 -fold relative risk for developing prostate cancer and in a cumulative risk of $8.6 \%$ of developing prostate cancer by 65 years old [57]. Additionally, comparing prostate cancer in germline BRCA-mutated (gBRCAm) cases to sporadic prostate cancer, a study of 2019 patients found that gBRCAm is associated with Gleason $\geq 8$, T3/T4 stage, lymph node involvement, and metastatic disease at diagnosis [58]. This study also reported significantly worse cancer-specific survival in these patients compared to the noncarrier cohort, which was also validated in a different study [58,59], confirming the important role of genetics in prostate cancer development and prognosis.

Mutations in BRCA1/2 and ATM can be targeted with PARP inhibitors. There are currently four FDA-approved PARP inhibitors (olaparib, rucaparib, niraparib, talazoparib) for other gBRCAm cancers including ovarian and breast [60-65]. These drugs have shown significant survival advantages in gBRCAm patients and previous approvals in other tumor histologies have served as the scientific basis for the currently ongoing PARPi trials in prostate cancer [66,67].

Analysis of familial risk models has revealed the importance of HOXB13 G84E mutations in the development of early-onset prostate cancer [13]. A study in over 6000 patients, found that HOXB13 gene mutations were significantly more likely in individuals with prostate cancer compared to those without (OR 20.1; 95\% CI, 3.5-803.3) [13]. A follow-up meta-analysis looking at 25 case-control studies with a total of over 145,000 patients confirmed the increased risk for prostate cancer in HOXB13 G84E mutant carriers (OR 3.248; 95\% CI, 2.313-4.560; $p<0.001$ ) [68]. It remains to be demonstrated whether regular screening for HOXB13 G84E mutations in men with strong family history of prostate cancer can result in improved outcomes.

The CHEK2 gene, which has been well-established in breast cancer pathogenesis, also has ties to prostate cancer. A study including over 86,000 patients found that heterozygotes with CHEK2 mutations, were significantly more likely to develop prostate cancer than noncarriers (OR 1.60; 95\% CI, 1.00-2.56) [69]. In familial cases, CHEK2 mutations are associated with an increased risk of prostate cancer (OR 3.39; 95\% CI, 1.78-6.47) [70]. Additionally, a 45,000-patient case-control study on specific subset populations found that African men and European men with CHEK2 mutations has increased 
risk for developing prostate cancer (OR 3.03; 95\% CI, 1.53-6.03; $p=0.0006$ and OR 2.21; 95\% CI, $1.06-4.63 ; p=0.030$, respectively) [71].

\section{Testicular Cancer Genetics}

A study of 205 patients with TGCT found that $9.8 \%$ of patients had CHEK2 mutations and, compared to historical controls, patients with TGCT were significantly more likely to carry germline CHEK2 alteration (OR $>1.4 ; p=0.03)$ [72]. Additionally, carriers of CHEK2 mutations developed TGCTs almost six years earlier than those with TGCTs and wild-type CHEK2 (5.95 years; 95\% CI, 1.48-10.42; $p=0.009$ [72]. An analysis of 137 TGCTs identified three somatic mutations that were significantly altered in these patients: KIT (18\%), KRAS (14\%), and NRAS (4\%), all of which are potentially actionable with targeted therapeutics. KRAS was further validated in a 47-patient study as the most frequently altered gene [73,74]. These findings help elucidate the biology of TGCT, define genomic drivers of pathogenesis, and offer potentially actionable therapeutic targets.

The most commonly altered genes in TGCT identified are KIT, TP53, KRAS/NRAS, and BRAF [75]. Further, one study found that there were more mutations in KIT in patients with bilateral TGCT compared with unilateral disease ( $93 \%$ vs $1.3 \%$ ) [76]. One study found NRAS to be mutated in up to $65 \%$ of TGCT [77]. Additionally, BRAF V600E mutations were associated with chemoresistance, with $26 \%$ of cisplatin resistant TGCTs harboring BRAF V600E mutations comparing with only $1 \%$ in the cisplatin sensitive TGCTs [78].

In order to better identify the genomic landscape of TGCT, a five-patient phase II study analyzed targeted exome sequencing data of platinum-refractory TGCT who were treated with sunitinib. In this study, one patient had a progression-free survival of 17 months and was found to have RET amplification, PTEN loss, EGFR and KRAS amplifications [79]. Of these genes, the RET amplification was believed to be the driver mutation targeted by sunitinib, resulting in a profound response [79]. c-KIT mutations in TGCT may confer response to imatinib, but the clinical utility of this therapy for TGCT remains controversial [80].

\section{Analysis of The Cancer Genome Atlas (TCGA)—Last Accessed 13 March 2020}

We analyzed next-generation sequencing data from the Cancer Genome Atlas (TCGA) in an effort to elucidate the genomic landscape of these tumors (Figure 2). The figures were generated to show copy number alterations and mutations in selected genes. The figure panel was created using the cBioPortal [81] for the kidney (papillary [ $n=274]$, clear cell $[n=354]$ ), bladder urothelial $(n=406)$, prostate adenocarcinoma $(n=489)$, and testicular cancer $(n=144)$ data sets available on the portal. Patients with prostate adenocarcinoma had a higher frequency of mutations in genes related to DNA repair: BRCA2 (5\%), CHEK2 (1.6\%), ATM (6\%), as well as mutations in cell cycle regulating genes: RB1 $(10 \%)$ and TP53 (16\%). The papillary RCC dataset showed high mutation rates in the MET gene $(10 \%)$, which is targeted with MET inhibitors like cabozantinib [82] as well as mutations in PBRM1 (5\%) which can affect responses to immunotherapy [83]. The urothelial carcinoma dataset showed mutations in targetable genes such as FGFR3 (19\%), ATM (14\%), BRCA2 (13\%), PIK3CA (25\%), and ERBB2 (17\%) which may provide insight into future therapeutic strategies. The most commonly found mutation in the TCGT sample was KRAS (17\%) followed by KIT $(15 \%)$, which are both targetable and may affect platinum chemosensitivity and disease progression. 
AKT1 0.35 :

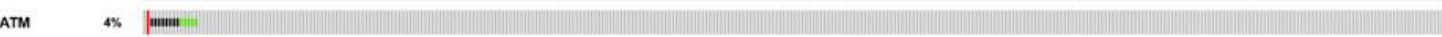

BAP1 $19 \%$ ||

BRCA1 $1.4 \%$

BRCA2 2.5\% | |

СНек2 $0.3 \%$

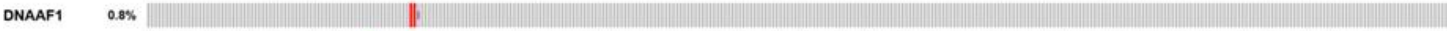

ERBв2 $1.1 \%$ |

FGFR2 $0.8 \%$

FGFR3 $0.3 \%$ |

FLCN $\quad 0.6 \%$

нохв13 $0.65 \mid$ |

HRAS $\quad 0.3 \%$

KIT

KRAS $\quad 0.8 \%$

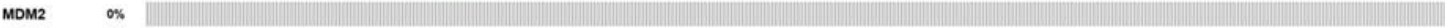

MEt $\quad 1.1 \%$

мsн6 $0.8 \%$ |

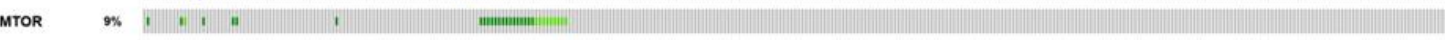

NRAS $0.3 \%$ -

PAL22 $0.6 \%$

PARP1 $0.65 \mid$ |

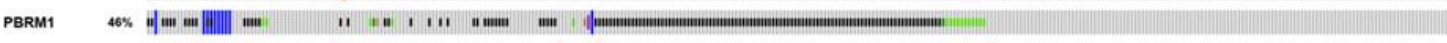

PIKзCA $4 \%$ |

PMs2 $0.6 \%$

RB1 $0.8 \%$ |

SMARCB1 $0.6 \%$

TP53

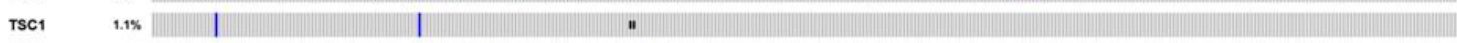

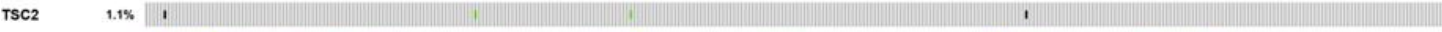

VHL $\quad 48 \%$ ๆ

sox4 $\quad 0.6 \%$

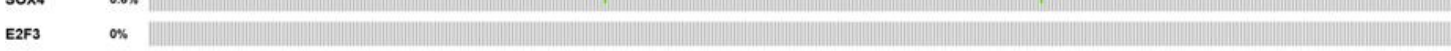

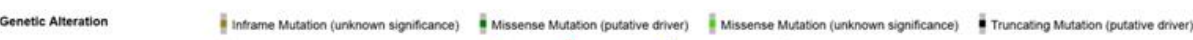

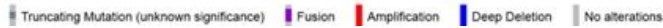

(a)

Figure 2. Cont. 
AKт1 AтM $\quad 2.0 \%$ | BAP1 $\quad 5 \%$ S BRCA1 BRCA2 $2.5 \%$ CHEK2 DNAAF1 $1.8 \%$ ERBB2 $1.1 \%$ |

FGF2

FGFs3 $2.0 \%$

FLCN

нохв13 0.45

HRAS $\quad$ ||

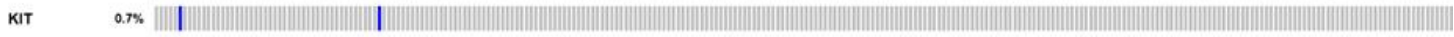

KRAs $\quad$ S.8s

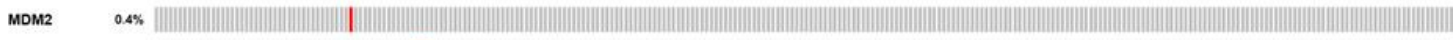

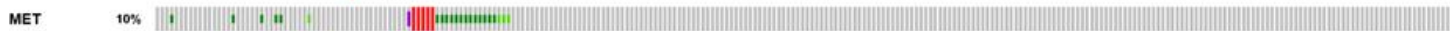

Msнs

Mtor

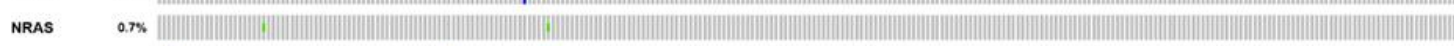

PALB2

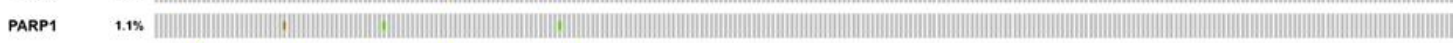

PBRm $5 \%, \quad$ P

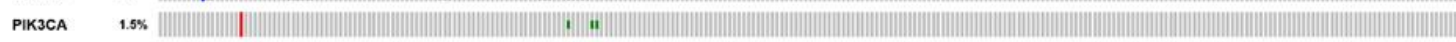

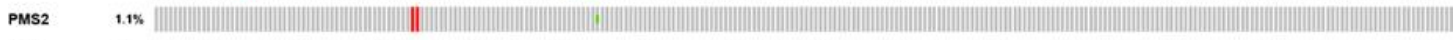

RB1 $\quad$ R.

SMARCB1

TP53 $2.8 \%$

Tsc1

Tsc2 $295 \%$

vHL

soxa E2F3

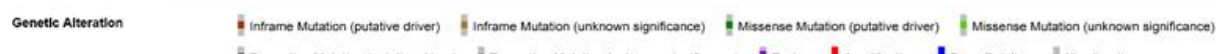

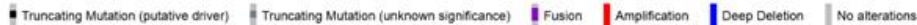

(b)

Figure 2. Cont. 


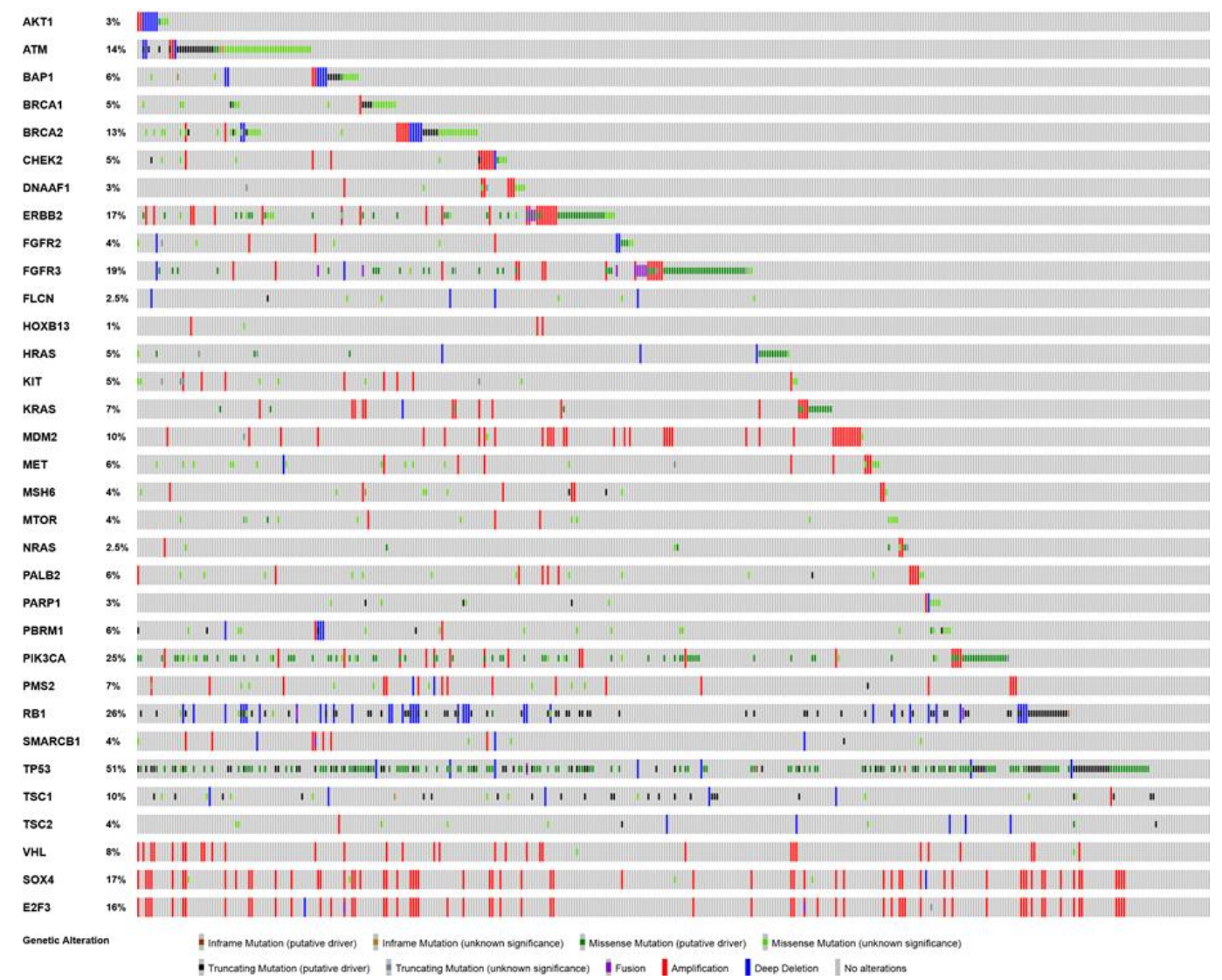

(c)

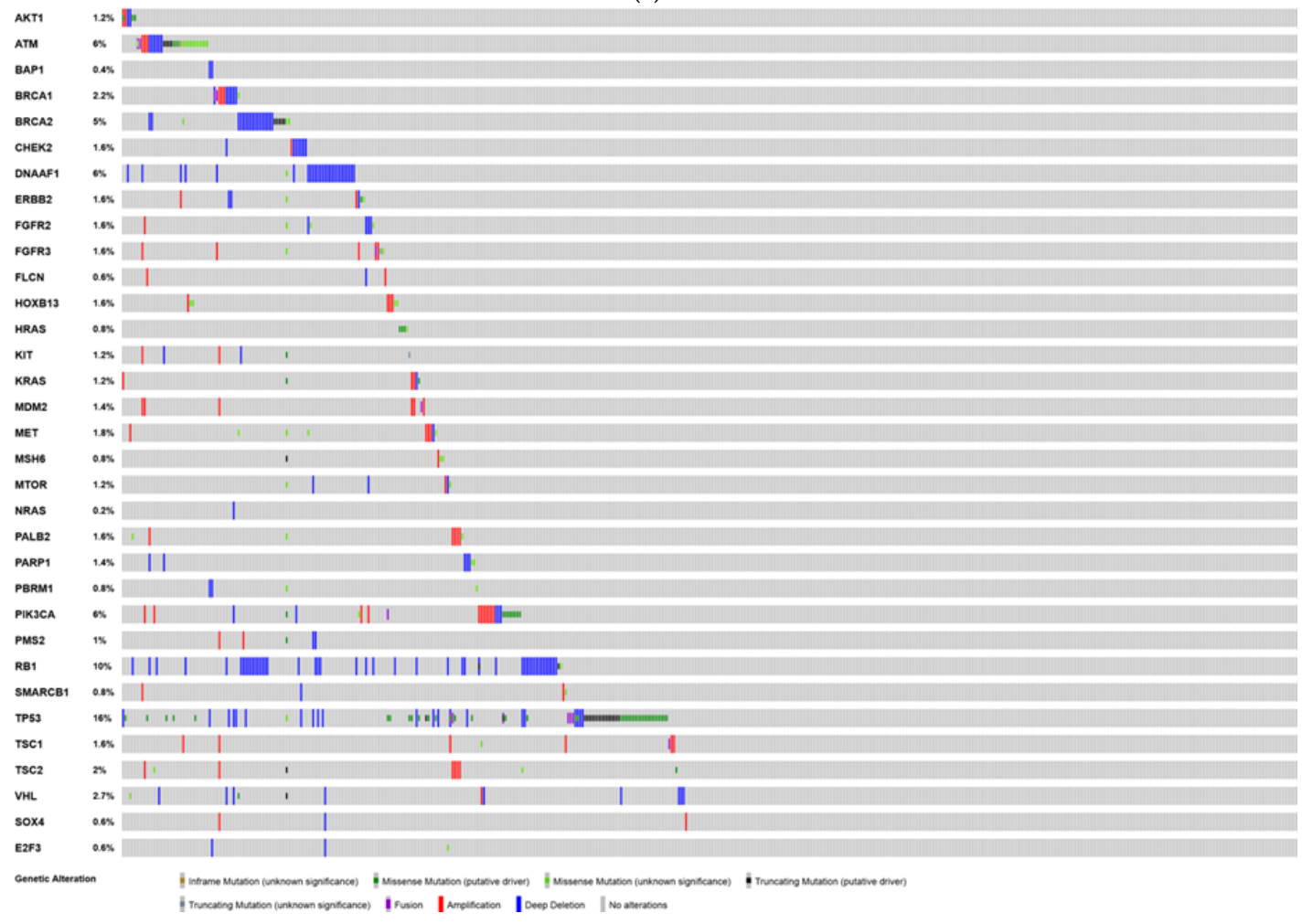

(d)

Figure 2. Cont. 


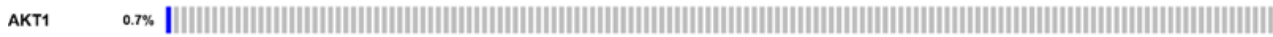

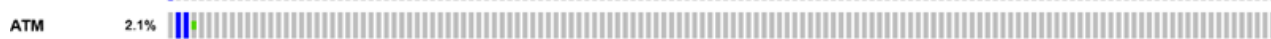

Bap1 $1.4 \%$.

BRCA1 $0 \%$.

Brcas $\quad$ o\%

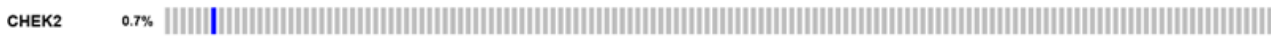

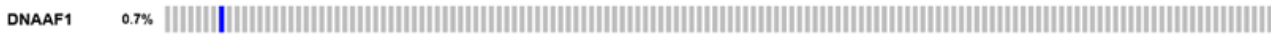

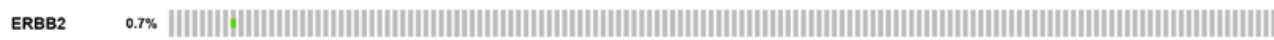

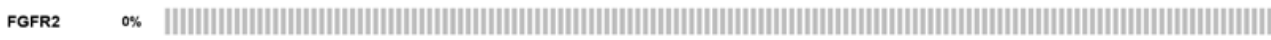

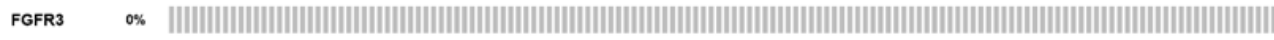

F.cs $\quad$ o.

roxs13

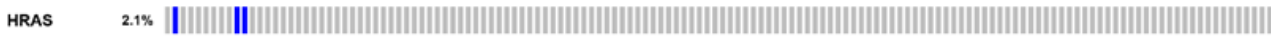

Kı $15 \%$ | 1 - 1 -

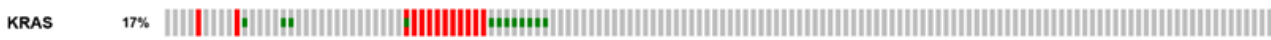

mom2 $2.8 \%$.

mes $\quad$ o\%

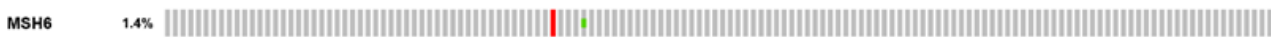

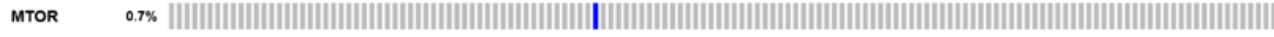

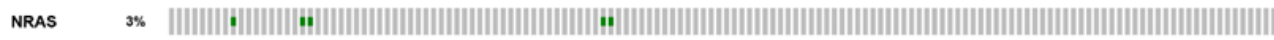

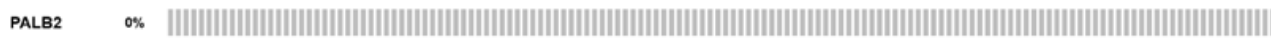

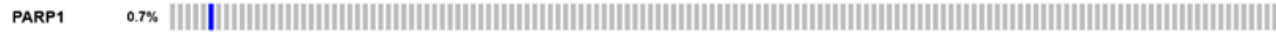

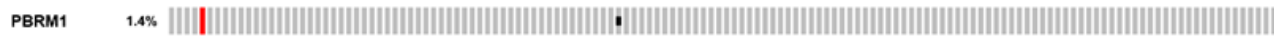

PІкзса

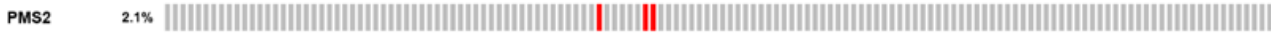

RB1 $0 \%$.

smarcs

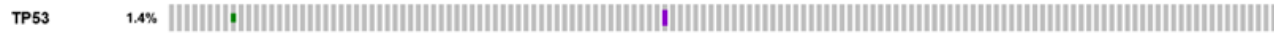

Tsc1 $0.7 \%$ |

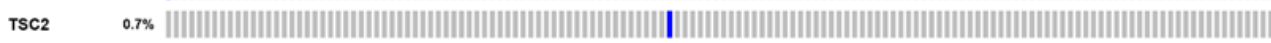

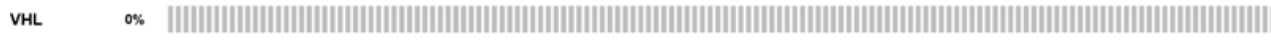

sox4 $\quad 0 \% \quad$.

e2ғ3

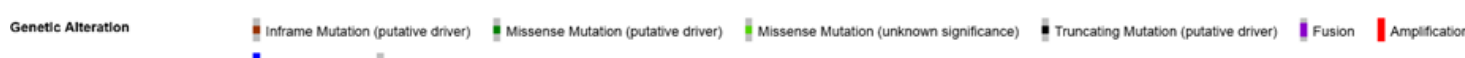
|Deep Deletion || No atterations

(e)

Figure 2. The Cancer Genome Atlas (TCGA) figure was generated to show copy number alterations, and mutations in selected genes. The figure panel was created using the cBioPortal [81] for the bladder, kidney (papillary and clear cell), bladder urothelial, and prostate data set available on the portal. Deep deletion denotes a deep copy number loss, potentially a homozygous deletion. Amplification denotes a high-level, often focal, copy number gain of multiple copies. Deep deletions and amplification are considered more biologically relevant than shallow deletions (which are often heterozygous) and low-level copy number gains. (a). clear cell renal cell carcinoma TCGA mutational landscape. (b). papillary renal cell carcinoma TCGA mutational landscape. (c). Bladder Urothelial Carcinoma TCGA mutational landscape. (d). Prostate adenocarcinoma TCGA mutational landscape. (e). Testicular cancer TCGA mutational landscape.

\section{Genitourinary Genetic Counseling for the Practicing Physician}

\subsection{Genetic Counseling Overview}

While it has been well established that there are a number of germline mutations associated with an increased risk of urologic malignancy, genetic counseling is an often-underutilized component of the work-up for cancer patients. Significant factors contributing to the underutilization of genetic testing are likely the lack of clear guidelines regarding how the results should be used to alter management and the shortage of genetic counselors. However, improvements are continuously being made [84-86]. Still, there remains a significant amount of work needed to better determine which patients should 
undergo genetic testing, the timeframe during which testing should be conducted, what techniques should be used, and how the information can be utilized to better serve patients and their families. Additionally, the decreasing cost and increasing number of available genetic tests has likely contributed to the demand for genetic counseling, which further exacerbates the lack of genetic counselors [84].

Genetic counseling is a field that helps patients navigate the complexities and implications of genetic testing, as genetic testing results can have significant medical, psychological, and familial consequences that patients are unsure how to address. It requires training in medical genetics through an Accreditation Council for Genetic Counseling (ACGC) accredited master's program and passing the American Board of Genetic Counseling (ABGC) certification exam [87]. As of 2017, there were just over 4200 certified genetic counselors in the US and that number is expected to increase over the coming years. However, there appears to be a lack of genetic counselors when compared to the demand, making it difficult for many patients to receive proper genetic counseling [88].

One manner in which this shortage may be addressed is by trained surgeons or medical oncologists taking a more proactive role in counseling patients about genetic testing. A possible arrangement could have oncologists performing the initial pre-test genetic counseling (i.e., explaining risks/benefits of testing, why patient should have testing), while patients with pathogenic mutations or variations of unknown significance (VUS) receive more thorough genetic counseling from a genetic counselor. This arrangement was recently assessed during the ENGAGE (Evaluating Streamlined Onco-genetic BRCA Testing and Counseling Model Among Patients with Ovarian Cancer) study where patients with ovarian cancer underwent BRCA mutation testing. The study demonstrated high rates of patient and oncologist satisfaction with the aforementioned model [89]. It is important to note this arrangement requires oncologists to have undergone adequate training in pre-test counseling, and for there to be a close partnership between oncologists and genetic counselors to ensure patients are receiving high-quality and timely care. One particular patient population that has been shown to receive suboptimal care at times is patients with genetic results demonstrating VUS. In a study where patients with breast cancer underwent BRCA testing, it was found that nearly half of the surgeons involved did not understand the difference between VUS and pathogenic mutations [90]. This is significant because a number of the patients with VUS underwent bilateral mastectomy, even though the procedure has only shown a survival benefit for those with a known pathogenic variant of the BRCA gene [91-93]. While these patients did not have urologic malignancy, this serves as an example of harm that can be done to patients if physicians do not understand the significance of genetic testing results.

\subsection{Genetic Testing and Prostate Cancer}

Of the urologic malignancies, genetic testing is likely to impact the management of prostate cancer more than others, namely due to the potential use of targeted therapies for patients with known germline mutations [86]. Currently, the National Comprehensive Cancer Network (NCCN) guidelines state patients with metastatic prostate cancer, patients with a Gleason score $\geq 7$ and a family history suspicious for possible high-risk germline mutations should undergo genetic counseling and consider genetic testing [94]. It is also worth noting that the NCCN guidelines state genetic testing is likely to be low-yield in patients with no family history suggestive of high-risk germline mutations, or prostate cancer with no suspicious clinical features (i.e., high or very-high risk prostate cancer, intraductal histology) [94]. Moreover, it is important the appropriate patents are selected for genetic testing as the results may cause unnecessary stress for patients, especially if testing shows VUS.

As to how the discovery of a pathogenic mutation can impact prostate cancer screening, the NCCN Prostate Cancer Early Detection Guidelines state men with known BRCA1/2 mutations should consider PSA screening at age 40 , as opposed to age 45 for average-risk men, following a discussion of risk and benefits. The NCCN states it is also reasonable to conduct repeat screening on an annual basis, regardless of the initial PSA value. There are no specific recommendations in regard to other germline mutations. Additionally, the NCCN states a PSA $\geq 3 \mathrm{ng} / \mathrm{mL}$ should be used as a cutoff for prostate biopsy (the same as their recommendation for men without pathogenic germline mutations) as there is 
not enough evidence to support a change in PSA cutoffs at this time. Currently, the IMPACT study is being conducted to aid the development of early detection guidelines for prostate cancer in men with BRCA1/2 germline mutations. Following the first round of screening, it has shown no difference between BRCA1/2 mutation carriers and controls in the rate of detection of prostate cancer or the positive predictive value of prostate biopsy in men with a PSA $\geq 3 \mathrm{ng} / \mathrm{mL}$. However, no conclusions can be made until more follow-up data are collected [95].

\subsection{Genetic Testing and Renal Cancer}

As aforementioned, there is a multitude of hereditary syndromes related to increased risk of kidney cancer. Many of these syndromes have extrarenal manifestations that can cause significant morbidity and mortality if not properly managed; hence, identifying patients with these conditions can have major implications for management of the patient and their family members. As far as who should be referred for genetic counseling, the NCCN and American Urological Association (AUA) recommend patients who are 46 years of age or younger with renal malignancy undergo genetic counseling $[96,97]$. The AUA also states genetic counseling should be considered for patients with multifocal or bilateral renal masses, or a personal or family history suggestive of hereditary renal neoplastic syndromes. Moreover, it is worth nothing these statements are considered "expert opinion" [97].

In patients who have family members with a known hereditary kidney cancer germline mutation, the age to start screening depends on the particular mutation. If it is a syndrome in which kidney cancer presents during adulthood, a discussion about screening can take place when the patient turns 18. However, if the syndrome is associated with childhood kidney cancer, screening during childhood should be considered [98]. At this time, the optimal screening modality for kidney cancer has not been determined, but urine dipstick, biomarkers, renal ultrasound, and abdominal CT scans have been used with various levels of success [99].

\subsection{Genetic Testing and Upper Tract Urothelial Carcinoma}

In addition to prostate and renal cancer, upper tract urothelial carcinoma (UTUC) can be linked to germline alterations. Specifically, Lynch syndrome is highly associated with UTUC, and is the most common inherited cancer syndrome. Lynch syndrome occurs due to defects in the DNA mismatch repair (MMR) system resulting in microsatellite instability (MSI), and ultimately leading to various types of cancer [100]. Per the European Association of Urology (EAU), the possibility UTUC is a manifestation of Lynch syndrome should be investigated with genetic testing in patients less than 60 years of age with hereditary nonpolyposis colorectal cancer (HNPCC) spectrum cancer, patients less than 60 years old with a 1st degree relative younger than 50 years old with a HNPCC-spectrum cancer, and patients less than 60 years old with two first degree relatives with HNPCC-spectrum cancers (i.e., colon, small bowel, stomach, pancreas, endometrium ovary, bladder) [101]. Moreover, the revised Bethesda guidelines can be used to select patients without UTUC who should be tested for Lynch syndrome [102].

The diagnosis of Lynch syndrome requires tissue testing and germline genetic testing [100]. If tumor tissue is available, immunohistochemistry and MSI-PCR should be performed to evaluate for the lack of MMR proteins and amount of MSI, respectively. Should these tests demonstrate a patient is at high risk for Lynch syndrome, through either a lack of proper MMR proteins (i.e., MLH1, MSH2, MSH6, or PMS2) or MSI-high, they should undergo germline genetic testing to confirm the diagnosis of Lynch syndrome [103]. Lastly, there is no clear consensus regarding how patients with Lynch Syndrome should be screened for urinary tract carcinoma. The EAU guidelines states patients with Lynch syndrome do not need to be screened for urinary tract cancer, while US guidelines say they can be screened for microscopic hematuria starting at age 30-35 [104,105]. 


\section{Conclusions}

Understanding the diverse genomic aberrations that lead to GU malignancies can guide the development of targeted therapeutic strategies. The key driver mutations in familial syndromic cancers have informed studies of key biological pathways. In RCC, well-described hereditary syndromes have served as real-time clinical models for the pathogenesis of sporadic cases with similar somatic gene alterations. Common bladder cancer genetic mutations can be targeted by rationally designed therapies. In prostate cancer, the large patient population has provided valuable data of genomic correlates for increased disease risk that can inform potential screening strategies. The discovery of new molecular markers in testicular cancer may also guide novel treatment strategies for the subset of patients with relapsed/refractory disease to cytotoxic chemotherapy. A better understanding of the molecular pathogenesis of urologic malignancies can expand the therapeutic armamentarium against these diseases and improve the outcomes of patients who are resistant to currently approved regimens.

Funding: This work was supported in part by the Cancer Center Support Grant to MDACC (grant number P30 CA016672) from the National Cancer Institute of the National Institutes of Health. PM is supported by a Young Investigator Award by the Kidney Cancer Association, a Career Development Award by the American Society of Clinical Oncology, a Research Grant Award by KCCure and by a Concept Award by the United States Department of Defense.

Conflicts of Interest: J.J.A., A.L., J.R., A.K.M., and G.G. have no disclosures. V.S. receives research funding for clinical trials from Novartis, Bayer, GlaxoSmithKline, Nanocarrier, Vegenics, Celgene, Northwest Biotherapeutics, Berghealth, Incyte, Fujifilm, Pharmamar, D3, Pfizer, Multivir, Amgen, Abbvie, Alfa-sigma, Agensys, Boston Biomedical, Idera Pharma, Inhibrx, Exelixis, Blueprint medicines, Loxo oncology, Takeda and Roche/ Genentech, National Comprehensive Cancer Network, NCI-CTEP, and UT MD Anderson Cancer Center. Travel: Novartis, Pharmamar, Astra Zeneca/Medimmune, Apollo Hospitals, Sathgen Biotech, ASCO, ESMO. None relevant to this viewpoint. P.M. receives research funding for clinical trials from Takeda, BMS, Mirati Therapeutics, Gateway for Cancer Research, and UT MD Anderson Cancer Center.

\section{References}

1. Haas, N.B.; Nathanson, K.L. Hereditary kidney cancer syndromes. Adv. Chronic Kidney Dis. 2014, 21, 81-90. [CrossRef] [PubMed]

2. Linehan, W.M. Genetic basis of kidney cancer: Role of genomics for the development of disease-based therapeutics. Genome Res. 2012, 22, 2089-2100. [CrossRef] [PubMed]

3. Hasumi, Y.; Baba, M.; Ajima, R.; Hasumi, H.; Valera, V.A.; Klein, M.E.; Haines, D.C.; Merino, M.J.; Hong, S.B.; Yamaguchi, T.P.; et al. Homozygous loss of BHD causes early embryonic lethality and kidney tumor development with activation of mTORC1 and mTORC2. Proc. Natl. Acad. Sci. USA 2009, 106, 18722-18727. [CrossRef] [PubMed]

4. Huang, K.L.; Mashl, R.J.; Wu, Y.; Ritter, D.I.; Wang, J.; Oh, C.; Paczkowska, M.; Reynolds, S.; Wyczalkowski, M.A.; Oak, N.; et al. Pathogenic Germline Variants in 10,389 Adult Cancers. Cell 2018, 173, 355-370. [CrossRef] [PubMed]

5. Ahmad, I.; Sansom, O.J.; Leung, H.Y. Exploring molecular genetics of bladder cancer: Lessons learned from mouse models. Dis. Models Mech. 2012, 5, 323-332. [CrossRef]

6. Zhang, X.; Zhang, Y. Bladder Cancer and Genetic Mutations. Cell Biochem. Biophys. 2015, 73, 65-69. [CrossRef]

7. Loriot, Y.; Necchi, A.; Park, S.H.; Garcia-Donas, J.; Huddart, R.; Burgess, E.; Fleming, M.; Rezazadeh, A.; Mellado, B.; Varlamov, S.; et al. Erdafitinib in Locally Advanced or Metastatic Urothelial Carcinoma. N. Engl. J. Med. 2019, 381, 338-348. [CrossRef]

8. Breast Cancer Linkage Consortium. Cancer risks in BRCA2 mutation carriers. J. Natl. Cancer Inst. 1999, 91, 1310-1316. [CrossRef]

9. Thompson, D.; Easton, D.; Breast Cancer Linkage Consortium. Variation in cancer risks, by mutation position, in BRCA2 mutation carriers. Am. J. Hum. Genet. 2001, 68, 410-419. [CrossRef]

10. Ostrander, E.A.; Udler, M.S. The role of the BRCA2 gene in susceptibility to prostate cancer revisited. Cancer Epidemiol. Biomark. Prev. 2008, 17, 1843-1848. [CrossRef] 
11. Schrader, K.A.; Cheng, D.T.; Joseph, V.; Prasad, M.; Walsh, M.; Zehir, A.; Ni, A.; Thomas, T.; Benayed, R.; Ashraf, A.; et al. Germline Variants in Targeted Tumor Sequencing Using Matched Normal DNA. JAMA Oncol. 2016, 2, 104-111. [CrossRef] [PubMed]

12. Annala, M.; Struss, W.J.; Warner, E.W.; Beja, K.; Vandekerkhove, G.; Wong, A.; Khalaf, D.; Seppala, I.L.; So, A.; Lo, G.; et al. Treatment Outcomes and Tumor Loss of Heterozygosity in Germline DNA Repair-deficient Prostate Cancer. Eur. Urol. 2017, 72, 34-42. [CrossRef] [PubMed]

13. Ewing, C.M.; Ray, A.M.; Lange, E.M.; Zuhlke, K.A.; Robbins, C.M.; Tembe, W.D.; Wiley, K.E.; Isaacs, S.D.; Johng, D.; Wang, Y.; et al. Germline mutations in HOXB13 and prostate-cancer risk. N. Engl. J. Med. 2012, 366, 141-149. [CrossRef]

14. Mateo, J.; Carreira, S.; Sandhu, S.; Miranda, S.; Mossop, H.; Perez-Lopez, R.; Nava Rodrigues, D.; Robinson, D.; Omlin, A.; Tunariu, N.; et al. DNA-Repair Defects and Olaparib in Metastatic Prostate Cancer. N. Engl. J. Med. 2015, 373, 1697-1708. [CrossRef] [PubMed]

15. National Comprehensive Cancer Network: NCCN Clinical Practice Guidelines in Oncology: Prostate Cancer. Available online: https://www.nccn.org/professionals/physician_gls/pdf/prostate_blocks.pdf (accessed on 6 May 2019).

16. Murray, M.J.; Turnbull, C. Testicular cancer in 2017: Sequencing advances understanding. Nat. Rev. Urol. 2018, 15, 79-80. [CrossRef] [PubMed]

17. Litchfield, K.; Levy, M.; Dudakia, D.; Proszek, P.; Shipley, C.; Basten, S.; Rapley, E.; Bishop, D.T.; Reid, A.; Huddart, R.; et al. Rare disruptive mutations in ciliary function genes contribute to testicular cancer susceptibility. Nat. Commun. 2016, 7, 13840. [CrossRef]

18. Jonasch, E.; McCutcheon, I.E.; Gombos, D.S.; Ahrar, K.; Perrier, N.D.; Liu, D.; Robichaux, C.C.; Villarreal, M.F.; Weldon, J.A.; Woodson, A.H.; et al. Pazopanib in patients with von Hippel-Lindau disease: A single-arm, single-centre, phase 2 trial. Lancet Oncol. 2018, 19, 1351-1359. [CrossRef]

19. Choueiri, T.K.; Plimack, E.; Arkenau, H.T.; Jonasch, E.; Heng, D.Y.C.; Powles, T.; Frigault, M.M.; Clark, E.A.; Handzel, A.A.; Gardner, H.; et al. Biomarker-Based Phase II Trial of Savolitinib in Patients with Advanced Papillary Renal Cell Cancer. J. Clin. Oncol. 2017, 35, 2993-3001. [CrossRef]

20. Zhang, T.; Gong, J.; Maia, M.C.; Pal, S.K. Systemic Therapy for Non-Clear Cell Renal Cell Carcinoma. Am. Soc. Clin. Oncol. Educ. Book 2017, 37, 337-342. [CrossRef]

21. Hartman, T.R.; Nicolas, E.; Klein-Szanto, A.; Al-Saleem, T.; Cash, T.P.; Simon, M.C.; Henske, E.P. The role of the Birt-Hogg-Dube protein in mTOR activation and renal tumorigenesis. Oncogene 2009, 28, 1594-1604. [CrossRef]

22. Baba, M.; Furihata, M.; Hong, S.B.; Tessarollo, L.; Haines, D.C.; Southon, E.; Patel, V.; Igarashi, P.; Alvord, W.G.; Leighty, R.; et al. Kidney-targeted Birt-Hogg-Dube gene inactivation in a mouse model: Erk1/2 and Akt-mTOR activation, cell hyperproliferation, and polycystic kidneys. J. Natl. Cancer Inst. 2008, 100, 140-154. [CrossRef] [PubMed]

23. Schmidt, L.S.; Linehan, W.M. Clinical Features, Genetics and Potential Therapeutic Approaches for Birt-Hogg-Dube Syndrome. Expert Opin. Orphan Drugs 2015, 3, 15-29. [CrossRef] [PubMed]

24. Turajlic, S.; Xu, H.; Litchfield, K.; Rowan, A.; Horswell, S.; Chambers, T.; O’Brien, T.; Lopez, J.I.; Watkins, T.B.K.; Nicol, D.; et al. Deterministic Evolutionary Trajectories Influence Primary Tumor Growth: TRACERx Renal. Cell 2018, 173, 595-610.e11. [CrossRef] [PubMed]

25. Mitchell, T.J.; Turajlic, S.; Rowan, A.; Nicol, D.; Farmery, J.H.R.; O’Brien, T.; Martincorena, I.; Tarpey, P.; Angelopoulos, N.; Yates, L.R.; et al. Timing the Landmark Events in the Evolution of Clear Cell Renal Cell Cancer: TRACERx Renal. Cell 2018, 173, 611-623. [CrossRef]

26. Turajlic, S.; Xu, H.; Litchfield, K.; Rowan, A.; Chambers, T.; Lopez, J.I.; Nicol, D.; O’Brien, T.; Larkin, J.; Horswell, S.; et al. Tracking Cancer Evolution Reveals Constrained Routes to Metastases: TRACERx Renal. Cell 2018, 173, 581-594. [CrossRef]

27. Ricketts, C.J.; Linehan, W.M. Multi-regional Sequencing Elucidates the Evolution of Clear Cell Renal Cell Carcinoma. Cell 2018, 173, 540-542. [CrossRef]

28. Chau, C.; van Doorn, R.; van Poppelen, N.M.; van der Stoep, N.; Mensenkamp, A.R.; Sijmons, R.H.; van Paassen, B.W.; van den Ouweland, A.M.W.; Naus, N.C.; van der Hout, A.H.; et al. Families with BAP1-Tumor Predisposition Syndrome in The Netherlands: Path to Identification and a Proposal for Genetic Screening Guidelines. Cancers 2019, 11, 1114. [CrossRef] 
29. Walpole, S.; Pritchard, A.L.; Cebulla, C.M.; Pilarski, R.; Stautberg, M.; Davidorf, F.H.; de la Fouchardiere, A.; Cabaret, O.; Golmard, L.; Stoppa-Lyonnet, D.; et al. Comprehensive Study of the Clinical Phenotype of Germline BAP1 Variant-Carrying Families Worldwide. J. Natl. Cancer Inst. 2018, 110, 1328-1341. [CrossRef]

30. Calderaro, J.; Masliah-Planchon, J.; Richer, W.; Maillot, L.; Maille, P.; Mansuy, L.; Bastien, C.; de la Taille, A.; Boussion, H.; Charpy, C.; et al. Balanced Translocations Disrupting SMARCB1 Are Hallmark Recurrent Genetic Alterations in Renal Medullary Carcinomas. Eur. Urol. 2016, 69, 1055-1061. [CrossRef]

31. Alvarez, O.A. Renal Medullary Carcinoma: The Kidney Cancer That Affects Individuals With Sickle Cell Trait and Disease. J. Oncol. Pract. 2017, 13, 424-425. [CrossRef]

32. Lopez-Beltran, A.; Cheng, L.; Raspollini, M.R.; Montironi, R. SMARCB1/INI1 Genetic Alterations in Renal Medullary Carcinomas. Eur. Urol. 2016, 69, 1062-1064. [CrossRef] [PubMed]

33. Msaouel, P.; Tannir, N.M.; Walker, C.L. A Model Linking Sickle Cell Hemoglobinopathies and SMARCB1 Loss in Renal Medullary Carcinoma. Clin. Cancer Res. 2018, 24, 2044-2049. [CrossRef] [PubMed]

34. Carugo, A.; Minelli, R.; Sapio, L.; Soeung, M.; Carbone, F.; Robinson, F.S.; Tepper, J.; Chen, Z.; Lovisa, S.; Svelto, M.; et al. p53 Is a Master Regulator of Proteostasis in SMARCB1-Deficient Malignant Rhabdoid Tumors. Cancer Cell 2019, 35, 204-220. [CrossRef] [PubMed]

35. Hong, A.L.; Tseng, Y.Y.; Wala, J.A.; Kim, W.J.; Kynnap, B.D.; Doshi, M.B.; Kugener, G.; Sandoval, G.J.; Howard, T.P.; Li, J.; et al. Renal medullary carcinomas depend upon SMARCB1 loss and are sensitive to proteasome inhibition. Elife 2019, 8, e44161. [CrossRef] [PubMed]

36. Linehan, W.M.; Rouault, T.A. Molecular pathways: Fumarate hydratase-deficient kidney cancer-targeting the Warburg effect in cancer. Clin. Cancer Res. 2013, 19, 3345-3352. [CrossRef] [PubMed]

37. Ohe, C.; Smith, S.C.; Sirohi, D.; Divatia, M.; de Peralta-Venturina, M.; Paner, G.P.; Agaimy, A.; Amin, M.B.; Argani, P.; Chen, Y.B.; et al. Reappraisal of Morphologic Differences Between Renal Medullary Carcinoma, Collecting Duct Carcinoma, and Fumarate Hydratase-deficient Renal Cell Carcinoma. Am. J. Surg. Pathol. 2018, 42, 279-292. [CrossRef]

38. Linehan, W.M.; Spellman, P.T.; Ricketts, C.J.; Creighton, C.J.; Fei, S.S.; Davis, C.; Wheeler, D.A.; Murray, B.A.; Schmidt, L.; Cancer Genome Atlas Research Network; et al. Comprehensive Molecular Characterization of Papillary Renal-Cell Carcinoma. N. Engl. J. Med. 2016, 374, 135-145. [CrossRef]

39. Murta-Nascimento, C.; Silverman, D.T.; Kogevinas, M.; García-Closas, M.; Rothman, N.; Tardón, A.; García-Closas, R.; Serra, C.; Carrato, A.; Villanueva, C.; et al. Risk of Bladder Cancer Associated with Family History of Cancer: Do Low-Penetrance Polymorphisms Account for the Increase in Risk? Cancer Epidemiol. Biomark. Prev. 2007, 16, 1595-1600. [CrossRef]

40. Van der Post, R.S.; Kiemeney, L.A.; Ligtenberg, M.J.L.; Witjes, J.A.; Hulsbergen-van de Kaa, C.A.; Bodmer, D.; Schaap, L.; Kets, C.M.; van Krieken, J.H.J.M.; Hoogerbrugge, N. Risk of urothelial bladder cancer in Lynch syndrome is increased, in particular among MSH2 mutation carriers. J. Med Genet. 2010, 47, 464-470. [CrossRef]

41. Mancini, M.; Righetto, M.; Baggio, G. Spotlight on gender-specific disparities in bladder cancer. Urol. J. 2019. [CrossRef]

42. Hurst, C.D.; Alder, O.; Platt, F.M.; Droop, A.; Stead, L.F.; Burns, J.E.; Burghel, G.J.; Jain, S.; Klimczak, L.J.; Lindsay, H.; et al. Genomic Subtypes of Non-invasive Bladder Cancer with Distinct Metabolic Profile and Female Gender Bias in KDM6A Mutation Frequency. Cancer Cell 2017, 32, 701-715. [CrossRef] [PubMed]

43. Kang, H.W.; Kim, Y.H.; Jeong, P.; Park, C.; Kim, W.T.; Ryu, D.H.; Cha, E.J.; Ha, Y.S.; Kim, T.H.; Kwon, T.G.; et al. Expression levels of FGFR3 as a prognostic marker for the progression of primary pT1 bladder cancer and its association with mutation status. Oncol. Lett. 2017, 14, 3817-3824. [CrossRef] [PubMed]

44. Pichler, R.; Horninger, W.; Heidegger, I. ASCO 2018: Highlights of urothelial cancer and prostate cancer. Memo 2018, 11, 284-290. [CrossRef] [PubMed]

45. Jebar, A.H.; Hurst, C.D.; Tomlinson, D.C.; Johnston, C.; Taylor, C.F.; Knowles, M.A. FGFR3 and Ras gene mutations are mutually exclusive genetic events in urothelial cell carcinoma. Oncogene 2005, 24, 5218-5225. [CrossRef] [PubMed]

46. Kompier, L.C.; Lurkin, I.; van der Aa, M.N.; van Rhijn, B.W.; van der Kwast, T.H.; Zwarthoff, E.C. FGFR3, HRAS, KRAS, NRAS and PIK3CA mutations in bladder cancer and their potential as biomarkers for surveillance and therapy. PLoS ONE 2010, 5, e13821. [CrossRef] [PubMed] 
47. Sjodahl, G.; Lauss, M.; Gudjonsson, S.; Liedberg, F.; Hallden, C.; Chebil, G.; Mansson, W.; Hoglund, M.; Lindgren, D. A systematic study of gene mutations in urothelial carcinoma; inactivating mutations in TSC2 and PIK3R1. PLOS ONE 2011, 6, e18583. [CrossRef]

48. Yan, M.; Schwaederle, M.; Arguello, D.; Millis, S.Z.; Gatalica, Z.; Kurzrock, R. HER2 expression status in diverse cancers: Review of results from 37,992 patients. Cancer Metast. Rev. 2015, 34, 157-164. [CrossRef]

49. Powles, T.; Huddart, R.A.; Elliott, T.; Sarker, S.-J.; Ackerman, C.; Jones, R.; Hussain, S.; Crabb, S.; Jagdev, S.; Chester, J.; et al. Phase III, Double-Blind, Randomized Trial That Compared Maintenance Lapatinib Versus Placebo After First-Line Chemotherapy in Patients With Human Epidermal Growth Factor Receptor 1/2-Positive Metastatic Bladder Cancer. J. Clin. Oncol. 2017, 35, 48-55. [CrossRef]

50. Koshkin VS, O.D.P.; Yu, E.Y.; Grivas, P. Systematic Review: Targeting HER2 in Bladder Cancer. Bladder Cancer 2019, 5, 1-12. [CrossRef]

51. Carter, B.S.; Beaty, T.H.; Steinberg, G.D.; Childs, B.; Walsh, P.C. Mendelian inheritance of familial prostate cancer. Proc. Natl. Acad. Sci. USA 1992, 89, 3367-3371. [CrossRef]

52. Hjelmborg, J.B.; Scheike, T.; Holst, K.; Skytthe, A.; Penney, K.L.; Graff, R.E.; Pukkala, E.; Christensen, K.; Adami, H.O.; Holm, N.V.; et al. The heritability of prostate cancer in the Nordic Twin Study of Cancer. Cancer Epidemiol. Biomark. Prev. 2014, 23, 2303-2310. [CrossRef] [PubMed]

53. Page, W.F.; Braun, M.M.; Partin, A.W.; Caporaso, N.; Walsh, P. Heredity and prostate cancer: A study of World War II veteran twins. Prostate 1997, 33, 240-245. [CrossRef]

54. Pritchard, C.C.; Mateo, J.; Walsh, M.F.; De Sarkar, N.; Abida, W.; Beltran, H.; Garofalo, A.; Gulati, R.; Carreira, S.; Eeles, R.; et al. Inherited DNA-Repair Gene Mutations in Men with Metastatic Prostate Cancer. N. Engl. J. Med. 2016, 375, 443-453. [CrossRef] [PubMed]

55. Agalliu, I.; Gern, R.; Leanza, S.; Burk, R.D. Associations of high-grade prostate cancer with BRCA1 and BRCA2 founder mutations. Clin. Cancer Res. 2009, 15, 1112-1120. [CrossRef] [PubMed]

56. Castro, E.; Eeles, R. The role of BRCA1 and BRCA2 in prostate cancer. Asian J. Androl. 2012, 14, 409-414. [CrossRef] [PubMed]

57. Leongamornlert, D.; Mahmud, N.; Tymrakiewicz, M.; Saunders, E.; Dadaev, T.; Castro, E.; Goh, C.; Govindasami, K.; Guy, M.; O’Brien, L.; et al. Germline BRCA1 mutations increase prostate cancer risk. Br. J. Cancer 2012, 106, 1697-1701. [CrossRef]

58. Castro, E.; Goh, C.; Olmos, D.; Saunders, E.; Leongamornlert, D.; Tymrakiewicz, M.; Mahmud, N.; Dadaev, T.; Govindasami, K.; Guy, M.; et al. Germline BRCA mutations are associated with higher risk of nodal involvement, distant metastasis, and poor survival outcomes in prostate cancer. J. Clin. Oncol. 2013, 31, 1748-1757. [CrossRef]

59. Castro, E.; Goh, C.; Leongamornlert, D.; Saunders, E.; Tymrakiewicz, M.; Dadaev, T.; Govindasami, K.; Guy, M.; Ellis, S.; Frost, D.; et al. Effect of BRCA Mutations on Metastatic Relapse and Cause-specific Survival After Radical Treatment for Localised Prostate Cancer. Eur. Urol. 2015, 68, 186-193. [CrossRef]

60. Kim, G.; Ison, G.; McKee, A.E.; Zhang, H.; Tang, S.; Gwise, T.; Sridhara, R.; Lee, E.; Tzou, A.; Philip, R.; et al. FDA Approval Summary: Olaparib Monotherapy in Patients with Deleterious Germline BRCA-Mutated Advanced Ovarian Cancer Treated with Three or More Lines of Chemotherapy. Clin. Cancer Res. 2015, 21, 4257-4261. [CrossRef]

61. Balasubramaniam, S.; Beaver, J.A.; Horton, S.; Fernandes, L.L.; Tang, S.; Horne, H.N.; Liu, J.; Liu, C.; Schrieber, S.J.; Yu, J.; et al. FDA Approval Summary: Rucaparib for the Treatment of Patients with Deleterious BRCA Mutation-Associated Advanced Ovarian Cancer. Clin. Cancer Res. 2017, 23, 7165-7170. [CrossRef]

62. Hoy, S.M. Talazoparib: First Global Approval. Drugs 2018, 78, 1939-1946. [CrossRef]

63. Ison, G.; Howie, L.J.; Amiri-Kordestani, L.; Zhang, L.; Tang, S.; Sridhara, R.; Pierre, V.; Charlab, R.; Ramamoorthy, A.; Song, P.; et al. FDA Approval Summary: Niraparib for the Maintenance Treatment of Patients with Recurrent Ovarian Cancer in Response to Platinum-Based Chemotherapy. Clin. Cancer Res. 2018, 24, 4066-4071. [CrossRef] [PubMed]

64. Scott, L.J. Niraparib: First Global Approval. Drugs 2017, 77, 1029-1034. [CrossRef] [PubMed]

65. Adashek, J.J.; Jain, R.K.; Zhang, J. Clinical Development of PARP Inhibitors in Treating Metastatic Castration-Resistant Prostate Cancer. Cells 2019, 8, 860. [CrossRef] [PubMed]

66. Rimar, K.J.; Tran, P.T.; Matulewicz, R.S.; Hussain, M.; Meeks, J.J. The emerging role of homologous recombination repair and PARP inhibitors in genitourinary malignancies. Cancer 2017, 123, 1912-1924. [CrossRef] 
67. Geethakumari, P.R.; Schiewer, M.J.; Knudsen, K.E.; Kelly, W.K. PARP Inhibitors in Prostate Cancer. Curr. Treat. Options Oncol. 2017, 18, 37. [CrossRef]

68. Cai, Q.; Wang, X.; Li, X.; Gong, R.; Guo, X.; Tang, Y.; Yang, K.; Niu, Y.; Zhao, Y. Germline HOXB13 p.Gly84Glu mutation and cancer susceptibility: A pooled analysis of 25 epidemiological studies with 145,257 participates. Oncotarget 2015, 6, 42312-42321. [CrossRef]

69. Naslund-Koch, C.; Nordestgaard, B.G.; Bojesen, S.E. Increased Risk for Other Cancers in Addition to Breast Cancer for CHEK2*1100delC Heterozygotes Estimated From the Copenhagen General Population Study. J. Clin. Oncol. 2016, 34, 1208-1216. [CrossRef] [PubMed]

70. Hale, V.; Weischer, M.; Park, J.Y. CHEK2 $\left(^{*}\right)$ 1100delC Mutation and Risk of Prostate Cancer. Prostate Cancer 2014, 2014, 294575. [CrossRef]

71. Southey, M.C.; Goldgar, D.E.; Winqvist, R.; Pylkas, K.; Couch, F.; Tischkowitz, M.; Foulkes, W.D.; Dennis, J.; Michailidou, K.; van Rensburg, E.J.; et al. PALB2, CHEK2 and ATM rare variants and cancer risk: Data from COGS. J. Med. Genet. 2016, 53, 800-811. [CrossRef]

72. AlDubayan, S.H.; Pyle, L.C.; Gamulin, M.; Kulis, T.; Moore, N.D.; Taylor-Weiner, A.; Hamid, A.A.; Reardon, B.; Wubbenhorst, B.; Godse, R.; et al. Association of Inherited Pathogenic Variants in Checkpoint Kinase 2 (CHEK2) With Susceptibility to Testicular Germ Cell Tumors. JAMA Oncol. 2019, 5, 514-522. [CrossRef] [PubMed]

73. Shen, H.; Shih, J.; Hollern, D.P.; Wang, L.; Bowlby, R.; Tickoo, S.K.; Thorsson, V.; Mungall, A.J.; Newton, Y.; Hegde, A.M.; et al. Integrated Molecular Characterization of Testicular Germ Cell Tumors. Cell Rep. 2018, 23, 3392-3406. [CrossRef] [PubMed]

74. Taylor-Weiner, A.; Zack, T.; O’Donnell, E.; Guerriero, J.L.; Bernard, B.; Reddy, A.; Han, G.C.; AlDubayan, S.; Amin-Mansour, A.; Schumacher, S.E.; et al. Genomic evolution and chemoresistance in germ-cell tumours. Nature 2016, 540, 114-118. [CrossRef] [PubMed]

75. Sheikine, Y.; Genega, E.; Melamed, J.; Lee, P.; Reuter, V.E.; Ye, H. Molecular genetics of testicular germ cell tumors. Am. J. Cancer Res. 2012, 2, 153-167. [PubMed]

76. McGlynn, K.A.; Cook, M.B. Etiologic factors in testicular germ-cell tumors. Future Oncol. 2009, 5, 1389-1402. [CrossRef]

77. Ganguly, S.; Murty, V.V.; Samaniego, F.; Reuter, V.E.; Bosl, G.J.; Chaganti, R.S. Detection of preferential NRAS mutations in human male germ cell tumors by the polymerase chain reaction. Genes Chromosomes Cancer 1990, 1, 228-232. [CrossRef]

78. Honecker, F.; Wermann, H.; Mayer, F.; Gillis, A.J.; Stoop, H.; van Gurp, R.J.; Oechsle, K.; Steyerberg, E.; Hartmann, J.T.; Dinjens, W.N.; et al. Microsatellite instability, mismatch repair deficiency, and BRAF mutation in treatment-resistant germ cell tumors. J. Clin. Oncol. 2009, 27, 2129-2136. [CrossRef]

79. Subbiah, V.; Meric-Bernstam, F.; Mills, G.B.; Shaw, K.R.; Bailey, A.M.; Rao, P.; Ward, J.F.; Pagliaro, L.C. Next generation sequencing analysis of platinum refractory advanced germ cell tumor sensitive to Sunitinib (Sutent(R)) a VEGFR2/PDGFRbeta/c-kit/ FLT3/RET/CSF1R inhibitor in a phase II trial. J. Hematol. Oncol. 2014, 7, 52. [CrossRef]

80. Fenner, M.H.; Beutel, G.; Grunwald, V. Targeted therapies for patients with germ cell tumors. Expert Opin. Investig. Drugs 2008, 17, 511-522. [CrossRef]

81. Cerami, E.; Gao, J.; Dogrusoz, U.; Gross, B.E.; Sumer, S.O.; Aksoy, B.A.; Jacobsen, A.; Byrne, C.J.; Heuer, M.L.; Larsson, E.; et al. The cBio cancer genomics portal: An open platform for exploring multidimensional cancer genomics data. Cancer Discov. 2012, 2, 401-404. [CrossRef]

82. Kurzrock, R.; Sherman, S.I.; Ball, D.W.; Forastiere, A.A.; Cohen, R.B.; Mehra, R.; Pfister, D.G.; Cohen, E.E.; Janisch, L.; Nauling, F.; et al. Activity of XL184 (Cabozantinib), an oral tyrosine kinase inhibitor, in patients with medullary thyroid cancer. J. Clin. Oncol. 2011, 29, 2660-2666. [CrossRef] [PubMed]

83. Braun, D.A.; Ishii, Y.; Walsh, A.M.; Van Allen, E.M.; Wu, C.J.; Shukla, S.A.; Choueiri, T.K. Clinical Validation of PBRM1 Alterations as a Marker of Immune Checkpoint Inhibitor Response in Renal Cell Carcinoma. JAMA Oncol. 2019, 5, 1631-1633. [CrossRef] [PubMed]

84. Delikurt, T.; Williamson, G.R.; Anastasiadou, V.; Skirton, H. A systematic review of factors that act as barriers to patient referral to genetic services. Eur. J. Hum. Genet. 2015, 23, 739-745. [CrossRef] [PubMed]

85. Das, S.; Salami, S.S.; Spratt, D.E.; Kaffenberger, S.D.; Jacobs, M.F.; Morgan, T.M. Bringing Prostate Cancer Germline Genetics into Clinical Practice. J. Urol. 2019, 202, 223-230. [CrossRef] [PubMed] 
86. Jacobs, M.F.; Milliron, K.J. Genetic counseling and previvorship in patients with urologic malignancies. Curr. Opin. Urol. 2019, 29, 371-377. [CrossRef] [PubMed]

87. Regier, D.S.; Ferreira, C.R.; Hart, S.; Hadley, D.W.; Muenke, M. Medical genetics and genomic medicine in the United States. Part 2: Reproductive genetics, newborn screening, genetic counseling, training, and registries. Mol. Genet. Genom. Med. 2017, 5, 621-630. [CrossRef] [PubMed]

88. Hoskovec, J.M.; Bennett, R.L.; Carey, M.E.; DaVanzo, J.E.; Dougherty, M.; Hahn, S.E.; LeRoy, B.S.; O’Neal, S.; Richardson, J.G.; Wicklund, C.A. Projecting the Supply and Demand for Certified Genetic Counselors: A Workforce Study. J. Genet. Couns. 2018, 27, 16-20. [CrossRef]

89. Colombo, N.; Huang, G.; Scambia, G.; Chalas, E.; Pignata, S.; Fiorica, J.; Van Le, L.; Ghamande, S.; Gonzalez-Santiago, S.; Bover, I.; et al. Evaluation of a Streamlined Oncologist-Led BRCA Mutation Testing and Counseling Model for Patients With Ovarian Cancer. J. Clin. Oncol. 2018, 36, 1300-1307. [CrossRef]

90. Kurian, A.W.; Li, Y.; Hamilton, A.S.; Ward, K.C.; Hawley, S.T.; Morrow, M.; McLeod, M.C.; Jagsi, R.; Katz, S.J. Gaps in Incorporating Germline Genetic Testing into Treatment Decision-Making for Early-Stage Breast Cancer. J. Clin. Oncol. 2017, 35, 2232-2239. [CrossRef]

91. Antoniou, A.; Pharoah, P.D.; Narod, S.; Risch, H.A.; Eyfjord, J.E.; Hopper, J.L.; Loman, N.; Olsson, H.; Johannsson, O.; Borg, A.; et al. Average risks of breast and ovarian cancer associated with BRCA1 or BRCA2 mutations detected in case Series unselected for family history: A combined analysis of 22 studies. Am. J. Hum. Genet. 2003, 72, 1117-1130. [CrossRef]

92. Domchek, S.M.; Friebel, T.M.; Singer, C.F.; Evans, D.G.; Lynch, H.T.; Isaacs, C.; Garber, J.E.; Neuhausen, S.L.; Matloff, E.; Eeles, R.; et al. Association of risk-reducing surgery in BRCA1 or BRCA2 mutation carriers with cancer risk and mortality. JAMA 2010, 304, 967-975. [CrossRef] [PubMed]

93. Rebbeck, T.R.; Friebel, T.; Lynch, H.T.; Neuhausen, S.L.; van't Veer, L.; Garber, J.E.; Evans, G.R.; Narod, S.A.; Isaacs, C.; Matloff, E.; et al. Bilateral prophylactic mastectomy reduces breast cancer risk in BRCA1 and BRCA2 mutation carriers: The PROSE Study Group. J. Clin. Oncol. 2004, 22, 1055-1062. [CrossRef] [PubMed]

94. Daly, M.B. Prostate cancer genetic testing: NCCN familial high-risk assessment: Breast/ovarian. Can. J. Urol. 2019, 26, 29-30. [PubMed]

95. Page, E.C.; Bancroft, E.K.; Brook, M.N.; Assel, M.; Hassan Al Battat, M.; Thomas, S.; Taylor, N.; Chamberlain, A.; Pope, J.; Raghallaigh, H.N.; et al. Interim Results from the IMPACT Study: Evidence for Prostate-specific Antigen Screening in BRCA2 Mutation Carriers. Eur. Urol. 2019, 76, 831-842. [CrossRef] [PubMed]

96. Motzer, R.J.; Jonasch, E.; Michaelson, M.D.; Nandagopal, L.; Gore, J.L.; George, S.; Alva, A.; Haas, N.; Harrison, M.R.; Plimack, E.R.; et al. NCCN Guidelines Insights: Kidney Cancer, Version 2.2020. J. Natl. Compr. Cancer Netw. 2019, 17, 1278-1285. [CrossRef]

97. Campbell, S.; Uzzo, R.G.; Allaf, M.E.; Bass, E.B.; Cadeddu, J.A.; Chang, A.; Clark, P.E.; Davis, B.J.; Derweesh, I.H.; Giambarresi, L.; et al. Renal Mass and Localized Renal Cancer: AUA Guideline. J. Urol. 2017, 198, 520-529. [CrossRef]

98. Lui, S.T.; Shuch, B. Genetic Testing in Kidney Cancer Patients: Who, When, and How? Eur. Urol. Focus 2019, 5, 973-976. [CrossRef]

99. Rossi, S.H.; Klatte, T.; Usher-Smith, J.; Stewart, G.D. Epidemiology and screening for renal cancer. World J. Urol. 2018, 36, 1341-1353. [CrossRef]

100. Pradere, B.; Lotan, Y.; Roupret, M. Lynch syndrome in upper tract urothelial carcinoma: Significance, screening, and surveillance. Curr. Opin. Urol. 2017, 27, 48-55. [CrossRef]

101. Roupret, M.; Babjuk, M.; Comperat, E.; Zigeuner, R.; Sylvester, R.J.; Burger, M.; Cowan, N.C.; Gontero, P.; Van Rhijn, B.W.G.; Mostafid, A.H.; et al. European Association of Urology Guidelines on Upper Urinary Tract Urothelial Carcinoma: 2017 Update. Eur. Urol. 2018, 73, 111-122. [CrossRef]

102. Pinol, V.; Castells, A.; Andreu, M.; Castellvi-Bel, S.; Alenda, C.; Llor, X.; Xicola, R.M.; Rodriguez-Moranta, F.; Paya, A.; Jover, R.; et al. Accuracy of revised Bethesda guidelines, microsatellite instability, and immunohistochemistry for the identification of patients with hereditary nonpolyposis colorectal cancer. JAMA 2005, 293, 1986-1994. [CrossRef] [PubMed]

103. Gupta, S.; Provenzale, D.; Llor, X.; Halverson, A.L.; Grady, W.; Chung, D.C.; Haraldsdottir, S.; Markowitz, A.J.; Slavin, T.P., Jr.; Hampel, H.; et al. NCCN Guidelines Insights: Genetic/Familial High-Risk Assessment: Colorectal, Version 2.2019. J. Natl. Compr. Cancer Netw. 2019, 17, 1032-1041. [CrossRef] [PubMed] 
104. Giardiello, F.M.; Allen, J.I.; Axilbund, J.E.; Boland, C.R.; Burke, C.A.; Burt, R.W.; Church, J.M.; Dominitz, J.A.; Johnson, D.A.; Kaltenbach, T.; et al. Guidelines on genetic evaluation and management of Lynch syndrome: A consensus statement by the US Multi-Society Task Force on colorectal cancer. Gastroenterology 2014, 147, 502-526. [CrossRef] [PubMed]

105. Vasen, H.F.; Blanco, I.; Aktan-Collan, K.; Gopie, J.P.; Alonso, A.; Aretz, S.; Bernstein, I.; Bertario, L.; Burn, J.; Capella, G.; et al. Revised guidelines for the clinical management of Lynch syndrome (HNPCC): Recommendations by a group of European experts. Gut 2013, 62, 812-823. [CrossRef] [PubMed]

(C) 2020 by the authors. Licensee MDPI, Basel, Switzerland. This article is an open access article distributed under the terms and conditions of the Creative Commons Attribution (CC BY) license (http://creativecommons.org/licenses/by/4.0/). 